\title{
Effects of day of gestation and feeding regimen in Holstein × Gyr cows: II. Maternal and fetal visceral organ mass
}

\author{
P. P. Rotta, ${ }^{*}{ }^{1}$ S. C. Valadares Filho, ${ }^{*}$ T. R. S. Gionbelli, ${ }^{*}$ L. F. Costa e Silva, ${ }^{*} \dagger$ T. E. Engle, $\dagger$ M. I. Marcondes, ${ }^{*}$ \\ M. M. Campos, $\ddagger$ A. C. B. Menezes, ${ }^{*}$ and A. A. G. Lobo* \\ *Department of Animal Science, Universidade Federal de Viçosa, Viçosa, Brazil 36571-000 \\ †Department of Animal Science, Colorado State University, Fort Collins, 80523 \\ ‡Embrapa Gado de Leite, Juiz de Fora, Brazil 36038-330
}

\section{ABSTRACT}

This study investigated the influence of day of gestation (DG) and feeding regimens (FR) on maternal and fetal visceral organ mass in Holstein $\times$ Gyr cows. Forty-four pregnant multiparous Holstein $\times$ Gyr cows with an average initial body weight of $480 \pm 10.1 \mathrm{~kg}$ and an average initial age of $5 \pm 0.5 \mathrm{yr}$ were allocated to 1 of 2 FR: ad libitum (AL; $n=20$ ) or maintenance level $(\mathrm{ML} ; \mathrm{n}=24)$. Maintenance level was considered to be $1.15 \%$ of body weight (dry matter basis) and met $100 \%$ of the energy requirements; AL provided $190 \%$ of the total net energy requirements. Cows were individually fed a corn silage and concentrate-based diet composed of $93 \%$ roughage and $7 \%$ concentrate (dry matter basis) as a total mixed ration twice daily. Pregnant cows were slaughtered at 4 DG: $139(\mathrm{n}=11), 199(\mathrm{n}=11)$, $241(\mathrm{n}=11)$, and $268(\mathrm{n}=11) \mathrm{d}$, which was followed by necropsy. Mass of heart, liver, and gastrointestinal tract was heavier in AL- than in ML-fed cows. Mammary gland mass was heavier in AL- than in ML-fed cows, and the heaviest mass was observed at $268 \mathrm{~d}$ of gestation. Feeding regimen did not influence fetal body weight in this study. The majority of the visceral organ masses were similar in fetuses from cows fed AL or ML. These data indicate that maternal feed restriction does not affect the development of most fetal organs or fetal development; however, some maternal organs are affected by the FR provided. Moreover, the negative effect on mammary gland mass caused by ML feeding will probably not affect the subsequent lactation because the crude protein concentration in the mammary gland increased with ML feeding. However, we suggest that the AL diet in pregnant dry cows should be provided with caution because the amount of fat in the mammary gland increased at $268 \mathrm{~d}$ of gestation.

Received April 24, 2014.

Accepted January 11, 2015.

${ }^{1}$ Corresponding author: polyana.rotta@ufv.br
Key words: fetal development, gastrointestinal tract, mammary gland, small intestine

\section{INTRODUCTION}

Caloric needs for gestation in beef cattle increase approximately 5.5 times from early to late gestation, but approximately $50 \%$ of this increase can be accounted for by the needs of the gravid uterus (Scheaffer et al., 2001). Moreover, according to Ferrell (1988), visceral tissues are responsible for about $41 \%$ of total energy expenditure even though they only represent $6 \%$ of the empty body weight (EBW) in beef cows. In nonlactating dairy cows, Smith and Baldwin (1973) found that the liver accounts for $22.5 \%$ of the total animal energy expenditure. Thus, a feeding regimen (FR) that supplies nutritional requirements without compromising fetal development may provide an alternative that increases savings in nutritional costs for dairy cow production.

Few studies (He et al., 2013; Drackley et al., 2014) have been conducted to evaluate the effects of FR on maternal and fetal organ mass in dairy cows. Some studies have demonstrated that underfeeding during gestation can cause intrauterine growth restriction, which results in impaired development and potential long-term consequences (He et al., 2013). Growth of the mammary gland is significantly delayed by overfeeding in the later stages of the prepubertal period, thus resulting in reduced milk yield (Tucker, 1981; Sejrsen et al., 1983). However, overfeeding during the postpubertal period appears to have no ill effect on mammary growth (Tucker, 1981). However, no study has been conducted with pregnant Holstein $\times$ Gyr cows fed at different levels to evaluate the mammary gland composition and growth.

Some authors (Scheaffer et al., 2004a; Reed et al., 2007; Meyer et al., 2010b) have suggested that the dam may compensate for restricted diets by altering the size and morphology of the maternal gastrointestinal tract in response to gestation status and nutritional level to 
spare her offspring. However, in dairy cows, few studies (Drackley et al., 2014) have investigated the influence of FR on the gastrointestinal tract. We hypothesized that cows fed a maintenance level (ML) diet that does not result in BW loss during gestation would not negatively affect fetal development compared with an ad libitum (AL) diet; moreover, an AL diet increases the costs of production. Our objectives were therefore to evaluate the influence of DG and FR on maternal and fetal visceral organ mass and fetal development in Holstein $\times$ Gyr cows.

\section{MATERIALS AND METHODS}

All animal care and handling procedures were approved by the Animal Care and Use Committee of the Department of Animal Science of the Universidade Federal de Viçosa, Viçosa, Minas Gerais, Brazil, before initiation of the experiment.

\section{Animals and Management}

The management practices that were adopted for the animals in this present experiment were previously described in a companion paper (Rotta et al., 2015b). However, a brief description is provided as follows: 44 multiparous dry Holstein $\times$ Gyr cows with an average initial BW of $480 \pm 10.1 \mathrm{~kg}$ and age of $5 \pm 0.5 \mathrm{yr}$ were allocated to 1 of 2 FR: AL $(\mathrm{n}=20)$ or $\mathrm{ML}(\mathrm{n}=24)$. The average age of the cows used in this experiment was chosen with the aim of representing the average age of cows raised in Brazil (IBGE, 2009). Maintenance level was assumed to be $1.15 \%$ of $\mathrm{BW}$ (in DM basis). To evaluate the effects of different days of gestation (DG), pregnant cows were slaughtered at 4 DG. Each FR group (ML and AL) was randomly divided into 4 groups, with 5 cows from AL and 6 cows from ML slaughtered at 139, 199, 241, and $268 \mathrm{~d}$ of gestation. Cows were fed a corn silage and concentrate-based diet at a ratio of 93:7 (DM basis) as a TMR twice daily, with $60 \%$ in the morning and $40 \%$ in the afternoon (DM basis).

\section{Tissue Collection}

Preharvest handling of animals was in accordance with good animal welfare practices, and slaughtering procedures followed the Sanitary and Industrial Inspection Regulation for Animal Origin Products (Brasil, 1997). Slaughter was performed on the same calendar day for each DG. Feed was withheld overnight, but cows had ad libitum access to water. Cows were slaughtered at Universidade Federal de Viçosa by captive bolt stunning followed by exsanguination.
After exsanguination, the gravid uterus was immediately collected and the fetus removed. Maternal viscera were removed, dissected, and weighed. The digestive tract was gently stripped of fat and digesta, and the stomach complex and intestines were dissected. The esophagus was removed from its entry at the dorsal sac of the rumen and abomasum as well as from the intestine at the pyloric valve. The stomach complex was then divided into the reticulum-rumen, omasum, and abomasum, and each component was weighed. The dissection of the fetus and isolation of the gastrointestinal tract was performed similarly to that described by Meyer et al. (2010a); briefly, fetuses were dissected and the entire gastrointestinal tract was collected and gently stripped of fat and digesta. The stomach complex was isolated from the esophagus and the intestine at the pyloric valve and divided into reticulum-rumen, omasum, and abomasum. Each component was gently emptied and weighed. Small and large intestines were isolated, and their weight and length were recorded separately. The small intestine was then divided into duodenum, jejunum, and ileum in a manner similar to that described by Soto-Navarro et al. (2004), as follows. The duodenum was identified as the segment between the pylorus to a point directly adjacent to the entry of the gastrosplenic vein into the mesenteric vein. The jejunum was the segment from the caudal end of the duodenum to the junction of jejunum and ileum. This junction was determined by measuring $15 \mathrm{~cm}$ up the mesenteric vein from the convergence of the mesenteric and ileocecal veins, and then up the mesenteric arcade to the point of intestinal intersection. The ileum measurement was terminated at the ileocecal junction. The mammary gland was removed and cut in slices of approximately $4 \mathrm{~cm}^{2}$, which were then ground in a commercial meat mill. A sample of mammary gland tissue was collected after grinding, which was then lyophilized for later analyses. Mammary tissue samples were analyzed for DM (AOAC International, 2000) and ether extract (AOAC International, 2006).

\section{Statistical Analysis}

Before performing the statistical analysis, we tested the normality of variables and they were normally distributed. The experiment was analyzed as a $4 \times 2$ factorial design by using the MIXED procedure (SAS Inst. Inc., Cary, NC). Day of gestation (139, 199, 241, and $268 \mathrm{~d}$ ), maternal FR (AL vs. ML), and their interaction were included as fixed effects in the model. Means were separated using the LSMEANS option of SAS and were considered significant when $P \leq 0.10$. In the absence of an interaction between maternal FR $\times$ 
DG, main effects are reported; otherwise, interaction means are discussed.

\section{RESULTS}

\section{Maternal Viscera and Organ Mass}

We did not observe any interactions $(P=0.14)$ between FR and DG for the mass of claws (phalanges and external tissues), head, hide, blood, or mammary gland (Table 1$)$. However, heavier $(P=0.07)$ masses were observed for the claws and head in AL- than in ML-fed cows. In contrast, mass of both the claws and head were heavier $(P<0.01)$ in ML-fed cows expressed as gram per kilogram of EBW due to the lower BW of ML-fed cows.

The mass of hide and blood were heavier $(P<0.01)$ in AL- than in ML-fed cows (Table 1). Nevertheless, no difference $(P=0.27)$ was observed when those characteristics were expressed as grams per kilogram of EBW. Mammary gland mass was affected $(P<0.01)$ by FR. Ad libitum-fed cows had heavier $(P<0.01)$ mammary glands than ML-fed cows (Table 1). However, the concentration of $\mathrm{CP}$ in the mammary gland of ML-fed cows was greater $(P=0.09)$ than that of AL-fed cows at $268 \mathrm{~d}$ of gestation (Figure 1). Moreover, the concentration of fat in the mammary gland was greater $(P=$ 0.04) in AL-fed cows at $268 \mathrm{~d}$ of gestation than that in ML-fed cows (Figure 2). In addition, DG influenced ( $P$ $<0.01$ ) mammary gland mass (Table 1 ). Cows at 268 $\mathrm{d}$ of gestation were observed to have the heaviest $(P$ $<0.01)$ mammary gland. Mammary gland mass was heavier during late gestation, which coincides with the period of the most rapid fetal growth; in the last month of gestation, mammary gland mass increased by about $80.1 \pm 3.58 \%$ compared with the previous month (241 $\mathrm{d}$ of gestation).

No interaction $(P=0.11)$ was observed between DG and FR for mass of heart, liver, lungs, spleen, diaphragm, trachea plus esophagus or when those were expressed as grams per kilogram of EBW, and kidney expressed as kilograms (Table 2). However, an interaction $(P=0.06)$ between $\mathrm{DG}$ and $\mathrm{FR}$ was observed for kidneys expressed as grams per kilogram of EBW. Maintenance-fed cows had heavier $(P<0.01)$ kidneys expressed as grams per kilogram of EBW at 241 and $268 \mathrm{~d}$ of gestation than did AL-fed cows. We did not observe an effect $(P=0.41)$ on kidneys expressed as grams per kilogram of EBW in ML-fed cows among DG. However, AL-fed cows had lesser $(P=0.36)$ mass of kidney at 241 and $268 \mathrm{~d}$ than at $139 \mathrm{~d}$ of gestation.

Mass of heart, liver, kidneys, lungs, spleen, diaphragm, trachea plus esophagus, and liver and spleen expressed as grams per kilogram of EBW were heavier $(P=0.02)$

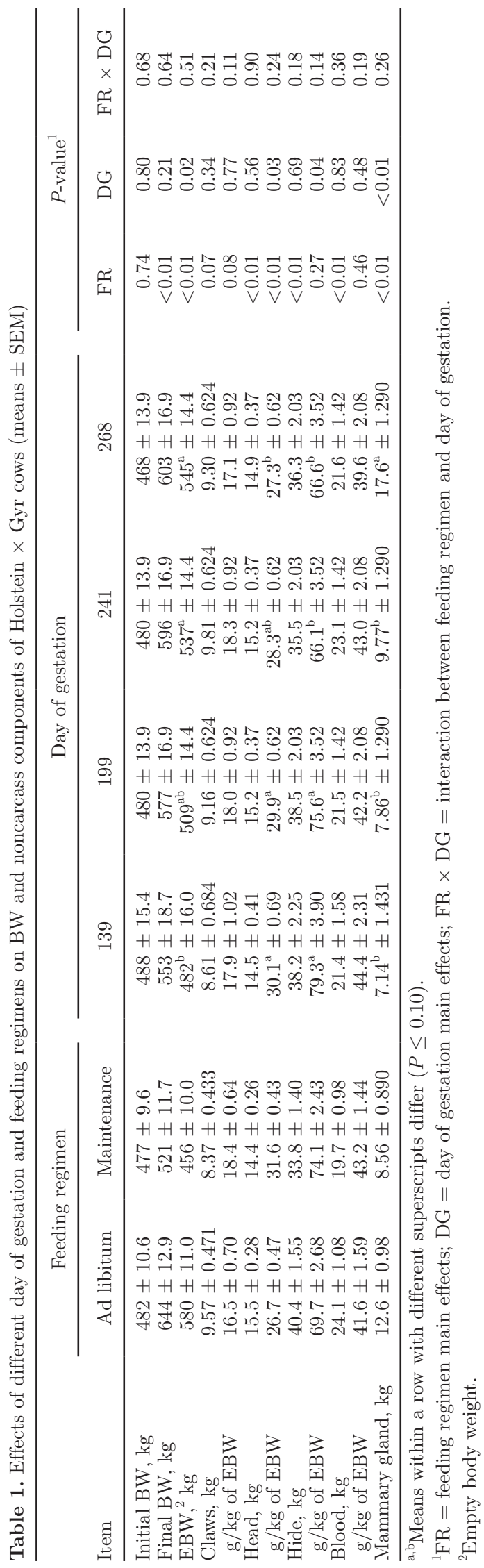

Journal of Dairy Science Vol. 98 No. 5, 2015 


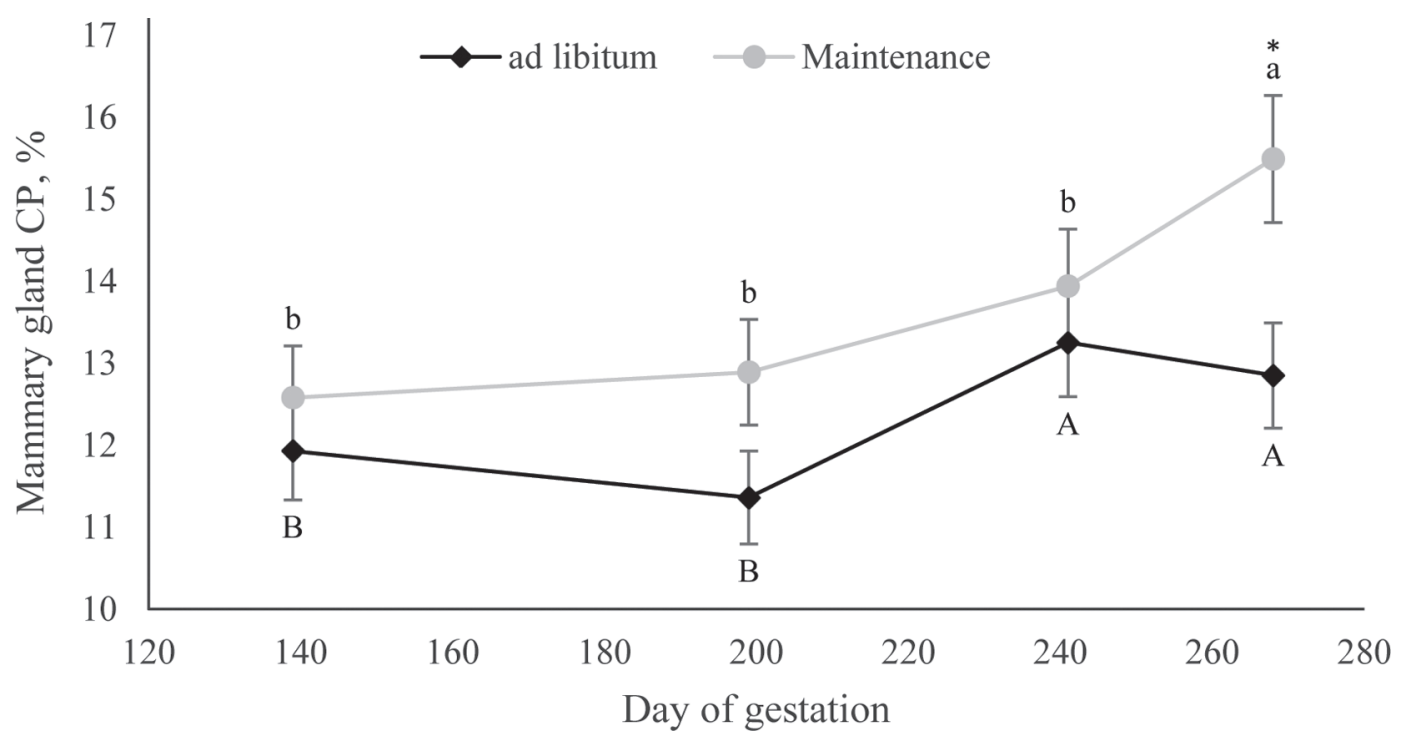

Figure 1. Crude protein concentrations in mammary gland of pregnant dry cows that were fed ad libitum or maintenance levels at different day of gestation. Results are means \pm SEM. ${ }^{*}$ Differed at $P \leq 0.10$; data points with different uppercase letters differ at $P \leq 0.10$ for ad libitum diets; different lowercase letters are different at $P \leq 0.10$ for maintenance diets.

in AL- than in ML-fed cows (Table 2). However, mass of the heart and lungs expressed as grams per kilogram of EBW were heavier $(P<0.01)$ in ML-fed cows.

Day of gestation affected $(P<0.01)$ mass of heart, liver, and spleen expressed as grams per kilogram of EBW as well as mass of the diaphragm and trachea plus esophagus (Table 2$)$. Heavier $(P<0.01)$ mass of heart, liver, and spleen expressed as grams per kilogram of EBW were observed for cows at 139 and 199 d than at 241 and $268 \mathrm{~d}$ of gestation. In contrast, heavier $(P$ $=0.08)$ mass of diaphragm and trachea plus esophagus were observed at $268 \mathrm{~d}$ than at $139 \mathrm{~d}$ of gestation, and no difference $(P=0.65)$ was found across 199,241 , and $268 \mathrm{~d}$ of gestation for the mass of trachea plus esophagus.

We detected no interaction $(P=0.19)$ between DG and FR for the mass of the reticulum-rumen, omasum, abomasum, or small and large intestines expressed as kilogram and grams per kilogram of EBW (Table 3). Effects $(P=0.09)$ of $\mathrm{FR}$ were observed on the mass of reticulum-rumen, omasum, abomasum, and small and large intestines, and for the abomasum and small

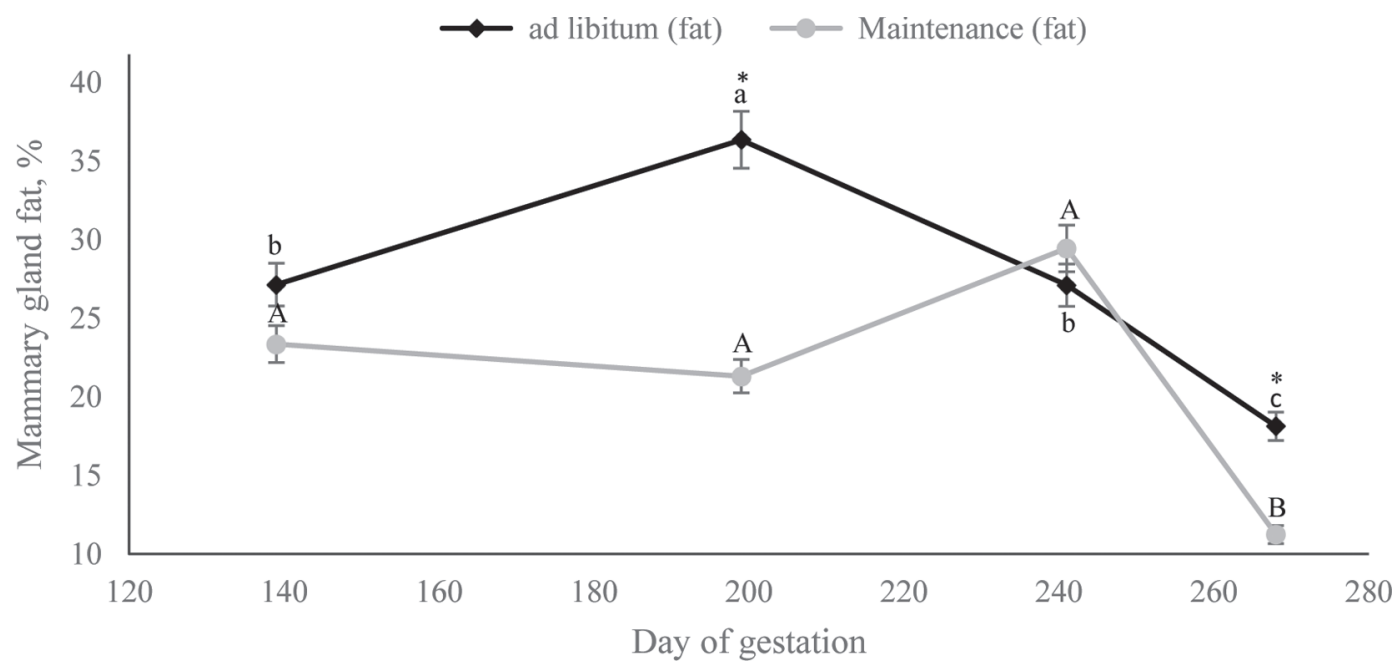

Figure 2. Fat concentrations in mammary gland of pregnant dry cows that were fed ad libitum and maintenance levels during gestation. Results are means \pm SEM. ${ }^{*}$ Differed at $P \leq 0.10$; data points with different lowercase letters differ at $P \leq 0.10$ for ad libitum diets; different uppercase letters are different at $P \leq 0.10$ for maintenance diets. 
Table 2. Effects of different day of gestation and feeding regimens on maternal organs in Holstein $\times$ Gyr cows (means \pm SEM)

\begin{tabular}{|c|c|c|c|c|c|c|c|c|c|}
\hline \multirow[b]{2}{*}{ Item } & \multicolumn{2}{|c|}{ Feeding regimen } & \multicolumn{4}{|c|}{ Day of gestation } & \multicolumn{3}{|c|}{$P$-value ${ }^{1}$} \\
\hline & Ad libitum & Maintenance & 139 & 199 & 241 & 268 & FR & DG & $\mathrm{FR} \times \mathrm{DG}$ \\
\hline Heart, $\mathrm{kg}$ & $2.07 \pm 0.061$ & $1.83 \pm 0.054$ & $1.89 \pm 0.082$ & $2.11 \pm 0.072$ & $1.97 \pm 0.072$ & $1.95 \pm 0.072$ & $<0.01$ & 0.11 & 0.56 \\
\hline $\mathrm{g} / \mathrm{kg}$ of $\mathrm{EBW}^{2}$ & $3.57 \pm 0.081$ & $4.01 \pm 0.076$ & $3.92^{\mathrm{a}} \pm 0.110$ & $4.15^{\mathrm{a}} \pm 0.101$ & $3.67^{\mathrm{b}} \pm 0.101$ & $3.58^{\mathrm{b}} \pm 0.101$ & $<0.01$ & $<0.01$ & 0.19 \\
\hline Liver, $\mathrm{kg}$ & $6.75 \pm 0.173$ & $4.94 \pm 0.150$ & $6.01 \pm 0.252$ & $6.22 \pm 0.220$ & $5.41 \pm 0.220$ & $5.64 \pm 0.220$ & $<0.01$ & 0.18 & 0.11 \\
\hline $\mathrm{g} / \mathrm{kg}$ of EBW & $11.6 \pm 0.240$ & $10.8 \pm 0.224$ & $12.5^{\mathrm{a}} \pm 0.35$ & $12.2^{\mathrm{a}} \pm 0.31$ & $10.1^{\mathrm{b}} \pm 0.31$ & $10.3^{\mathrm{b}} \pm 0.31$ & 0.02 & $<0.01$ & 0.12 \\
\hline Kidneys, kg & $1.17 \pm 0.035$ & $0.97 \pm 0.031$ & $1.10 \pm 0.054$ & $1.09 \pm 0.045$ & $0.99 \pm 0.045$ & $1.10 \pm 0.045$ & $<0.01$ & 0.24 & 0.32 \\
\hline $\mathrm{g} / \mathrm{kg}$ of EBW & $2.02 \pm 0.044$ & $2.13 \pm 0.047$ & $2.28 \pm 0.061$ & $2.14 \pm 0.053$ & $1.84 \pm 0.053$ & $2.01 \pm 0.053$ & 0.13 & $<0.01$ & 0.06 \\
\hline Ad libitum & - & - & $2.34^{\mathrm{a}, \mathrm{A}} \pm 0.104$ & $2.16^{\mathrm{ab}, \mathrm{A}} \pm 0.104$ & $1.73^{\mathrm{b}, \mathrm{B}} \pm 0.104$ & $1.87^{\mathrm{b}, \mathrm{B}} \pm 0.104$ & - & - & - \\
\hline Maintenance & - & - & $2.23^{\mathrm{a}, \mathrm{A}} \pm 0.102$ & $2.09^{\mathrm{a}, \mathrm{A}} \pm 0.094$ & $2.00^{\mathrm{a}, \mathrm{A}} \pm 0.094$ & $2.22^{\mathrm{a}, \mathrm{A}} \pm 0.094$ & - & - & - \\
\hline$P$-value & - & - & 0.66 & 0.26 & 0.04 & $<0.01$ & - & - & - \\
\hline Lungs, kg & $3.37 \pm 0.121$ & $2.98 \pm 0.102$ & $3.06 \pm 0.173$ & $3.27 \pm 0.157$ & $3.36 \pm 0.157$ & $3.42 \pm 0.157$ & 0.02 & 0.16 & 0.96 \\
\hline $\mathrm{g} / \mathrm{kg}$ of EBW & $5.81 \pm 0.170$ & $6.53 \pm 0.155$ & $6.35 \pm 0.254$ & $6.42 \pm 0.228$ & $6.26 \pm 0.228$ & $6.28 \pm 0.228$ & $<0.01$ & 0.13 & 0.51 \\
\hline Spleen, kg & $1.52 \pm 0.055$ & $1.08 \pm 0.054$ & $1.30 \pm 0.088$ & $1.44 \pm 0.075$ & $1.26 \pm 0.075$ & $1.18 \pm 0.075$ & $<0.01$ & 0.20 & 0.88 \\
\hline $\mathrm{g} / \mathrm{kg}$ of $\mathrm{EBW}$ & $2.62 \pm 0.072$ & $2.37 \pm 0.075$ & $2.70^{\mathrm{a}} \pm 0.115$ & $2.83^{\mathrm{a}} \pm 0.104$ & $2.35^{\mathrm{b}} \pm 0.104$ & $2.17^{\mathrm{b}} \pm 0.104$ & 0.01 & $<0.01$ & 0.51 \\
\hline Diaphragm, kg & $3.10 \pm 0.102$ & $2.33 \pm 0.090$ & $2.58^{\mathrm{b}} \pm 0.156$ & $2.78^{\mathrm{ab}} \pm 0.140$ & $2.79^{\mathrm{ab}} \pm 0.140$ & $2.99^{\mathrm{a}} \pm 0.140$ & $<0.01$ & 0.08 & 0.90 \\
\hline $\mathrm{g} / \mathrm{kg}$ of EBW & $5.34 \pm 0.154$ & $5.11 \pm 0.140$ & $5.35 \pm 0.227$ & $5.46 \pm 0.208$ & $5.20 \pm 0.208$ & $5.52 \pm 0.208$ & 0.19 & 0.12 & 0.34 \\
\hline Trachea plus esophagus, $\mathrm{kg}$ & $5.35 \pm 0.259$ & $4.18 \pm 0.236$ & $4.54^{\mathrm{b}} \pm 0.365$ & $5.28^{\mathrm{a}} \pm 0.339$ & $5.19^{\mathrm{a}} \pm 0.339$ & $5.04^{\mathrm{a}} \pm 0.339$ & $<0.01$ & 0.04 & 0.93 \\
\hline $\mathrm{g} / \mathrm{kg}$ of EBW & $9.22 \pm 0.388$ & $9.17 \pm 0.345$ & $9.42 \pm 0.550$ & $10.4 \pm 0.508$ & $9.66 \pm 0.508$ & $9.25 \pm 0.508$ & 0.91 & 0.13 & 0.90 \\
\hline
\end{tabular}

a,b Means within a row with different superscripts differ $(P \leq 0.10)$.

¿. $\quad{ }^{\mathrm{A}, \mathrm{B}}$ Means within a column with different superscripts differ $(P \leq 0.10)$.

$\stackrel{{ }^{1}}{\mathrm{FR}}=$ feeding regimen main effects; $\mathrm{DG}=$ day of gestation main effects; $\mathrm{FR} \times \mathrm{DG}=$ interaction between feeding regimen and day of gestation.

D. Empty body weight. 
and large intestines expressed as grams per kilogram of EBW. Abomasum and small and large intestines in ALfed cows were heavier $(P=0.09)$ than in ML-fed cows; however, these organs expressed as grams per kilogram of EBW were heavier in ML-fed cows $(P=0.07)$.

Day of gestation influenced $(P=0.07)$ reticulumrumen expressed as kilogram and grams per kilogram of EBW, and omasum and large intestine expressed as grams per kilogram of EBW. The reticulum-rumen was heavier $(P=0.07)$ at 139 than at $268 \mathrm{~d}$ of gestation, but reticulum-rumen expressed as grams per kilogram of EBW was heavier $(P<0.01)$ at 139 d than at 199 , 241 , and $268 \mathrm{~d}$ of gestation. Omasum and large intestine expressed as grams per kilogram of EBW were heavier $(P<0.01)$ at $139 \mathrm{~d}$ than at 241 and $268 \mathrm{~d}$ of gestation.

\section{Fetal Viscera and Organ Mass}

Fetal BW and measurements are presented in Table 4. No interaction $(P=0.11)$ between FR and DG was observed, although differences $(P=0.09)$ were observed between FR for the mass of claws, carcass weight expressed as grams per kilogram of fetal BW, fetal length, fetal chest length, fetal cranial circumference, and fetal hip height. Ad libitum-fed cows had the greatest values $(P=0.09)$ for these characteristics.

Day of gestation influenced $(P<0.01)$ all characteristics that were evaluated to investigate fetal development (fetal BW, fetal eviscerated BW, head, claws, and carcass weight, fetal length, chest length, cranial and neck circumferences, hip and withers height). Fetal BW, eviscerated BW, head, claws, and carcass weights were different $(P<0.01)$ among the studied DG, with the greatest values observed at $268 \mathrm{~d}$ and the lowest $(P$ $<0.01$ ) values at $139 \mathrm{~d}$ of gestation. Fetal BW increased approximately $50 \%(241 \mathrm{~d}=21.8 \pm 1.00 \mathrm{~kg}$ and 268 $\mathrm{d}=32.3 \pm 1.00 \mathrm{~kg}$ ) in the last month of gestation. During the last 4 mo of gestation, fetal BW increased approximately 20 -fold.

Fetal length, fetal chest length, cranial and neck circumference, hip and withers height were longer $(P<$ $0.01)$ at $268 \mathrm{~d}$ than at 139, 199, and $241 \mathrm{~d}$ of gestation. One exception to this was that cranial circumference was similar at 241 and $268 \mathrm{~d}$ of gestation.

Table 5 lists the mass of fetal visceral organs. We observed an interaction $(P=0.02)$ between FR and DG only for reticulum-rumen mass expressed as gram per kilogram of fetal BW. We observed that the mass of fetal reticulum-rumen expressed as gram per kilogram of fetal BW differed $(P<0.01)$ between AL- and MLfed cows at $139 \mathrm{~d}$ of gestation, and the fetal reticulumrumen expressed as gram per kilogram of fetal BW was heavier in AL- than ML-fed cows. Ad libitum and MLfed cows had lesser $(P<0.01)$ fetal reticulum-rumen

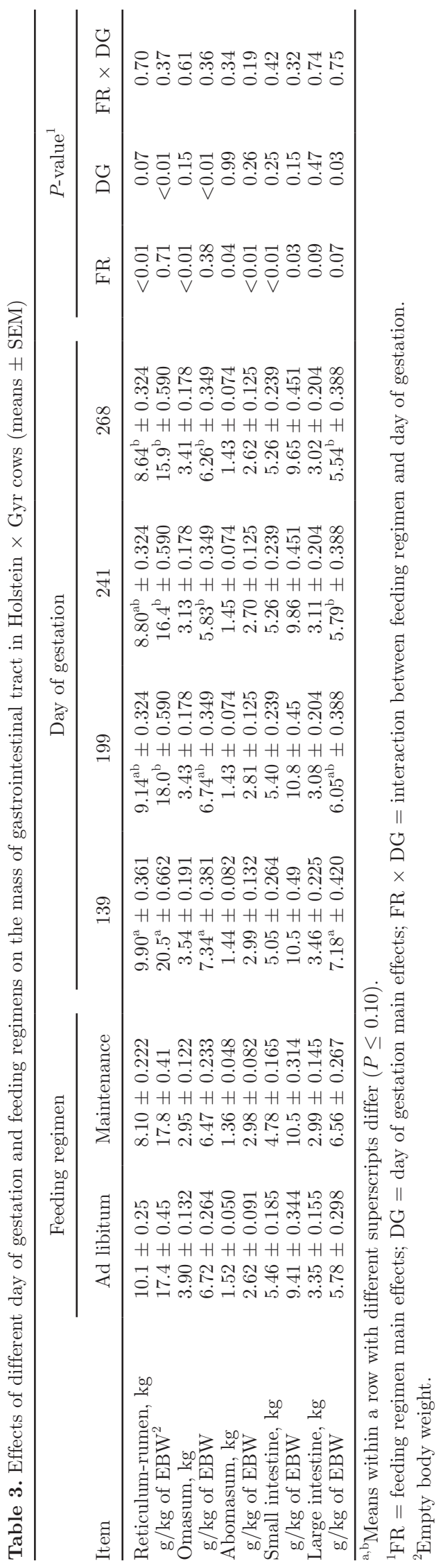




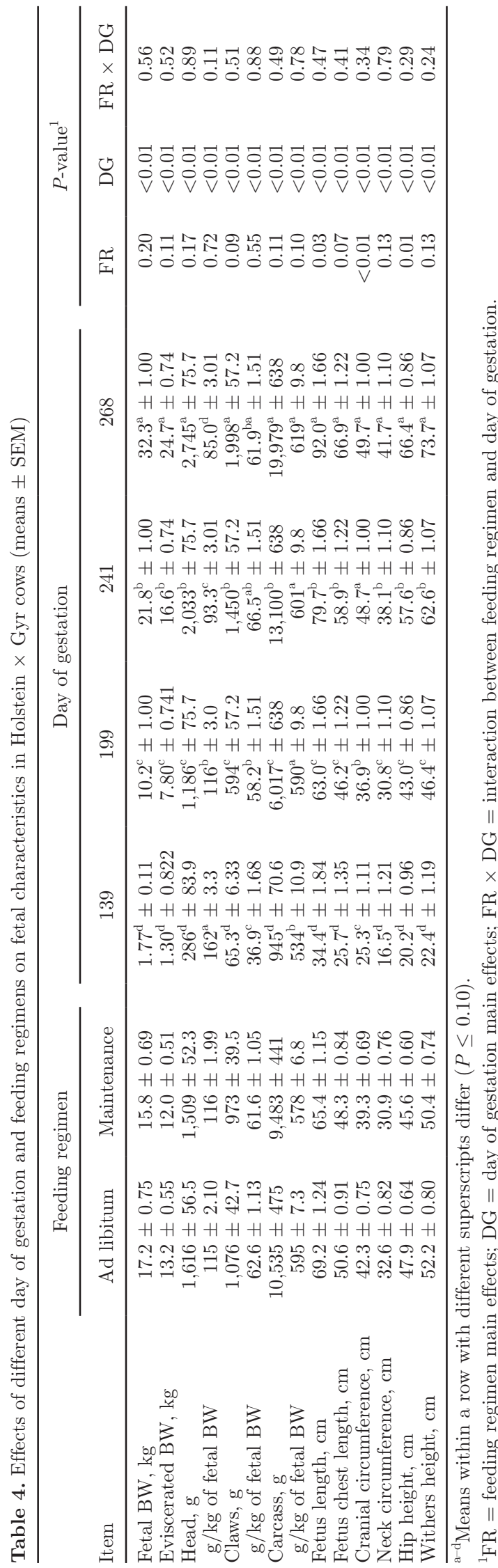

mass expressed as gram per kilogram of fetal BW at 241 and $268 \mathrm{~d}$ than at 139 and $199 \mathrm{~d}$ of gestation. However, for ML-fed cows, the mass was similar $(P=$ $0.03)$ at 139 and $199 \mathrm{~d}$ of gestation.

The only effects of FR observed on fetal visceral organ mass were on the bladder and diaphragm expressed as gram per kilogram of fetal BW. Maintenance-fed cows had heavier $(P<0.01)$ bladders expressed as grams per kilogram of fetal $\mathrm{BW}$ and lighter $(P=0.01)$ diaphragms expressed as grams per kilogram of fetal BW than AL-fed cows.

In contrast, DG affected fetal visceral organ mass. Mass of heart, liver, kidneys, lungs, reticulum-rumen, abomasum, spleen, bladder, gallbladder, and diaphragm were greater $(P<0.01)$ at $268 \mathrm{~d}$ than at 139,199 , and $241 \mathrm{~d}$ of gestation. At $241 \mathrm{~d}$, those masses were heavier $(P<0.01)$ than at 139 and $199 \mathrm{~d}$ of gestation; at $199 \mathrm{~d}$, heavier $(P<0.01)$ masses were observed than at $139 \mathrm{~d}$ of gestation. However, mass of omasum was similar $(P$ $=0.36$ ) between 241 and $268 \mathrm{~d}$ of gestation, but heavier $(P<0.01)$ than at 139 and $199 \mathrm{~d}$ of gestation. If we compare fetal visceral organs expressed as grams per kilogram of fetal BW, heart was heavier $(P<0.01)$ at 139 and $199 \mathrm{~d}$ than at 241 and $268 \mathrm{~d}$ of gestation. Liver and kidneys were heavier $(P<0.01)$ at $139 \mathrm{~d}$ than at 199, 241, and $268 \mathrm{~d}$ of gestation, and were heavier $(P$ $<0.01)$ at $199 \mathrm{~d}$ than at 241 and $268 \mathrm{~d}$ of gestation. The lungs had the greatest $(P<0.01)$ mass at $139 \mathrm{~d}$ and the least $(P<0.01)$ at $268 \mathrm{~d}$ of gestation. Omasum expressed as grams per kilogram of fetal BW had different $(P<0.01)$ results for all evaluated DG, with the greatest mass observed at $139 \mathrm{~d}$ of gestation. The mass of the abomasum, spleen, and diaphragm expressed as grams per kilogram of fetal BW did not differ $(P=$ 0.15 ) between the different DG.

The effects of FR and DG on the small and large intestines are presented in Table 6 . We observed an interaction $(P=0.06)$ of small intestine expressed as grams per kilogram of fetal BW. At 139 d of gestation, fetuses from AL-fed cows had greater $(P=0.04)$ small intestine mass than fetuses from ML-fed cows. No effect $(P=0.47)$ was observed at 199,241 , and 268 $\mathrm{d}$ of gestation in fetuses from AL- and ML-fed cows. Fetuses from AL-fed cows had greater $(P<0.01)$ small intestine mass at 139 and $199 \mathrm{~d}$ than at 241 and 268 d of gestation. Fetuses from ML-fed cows had greater $(P<0.01)$ small intestine mass at 199, 241, and $268 \mathrm{~d}$ than at $139 \mathrm{~d}$ of gestation.

Feeding regimen influenced $(P=0.04)$ the length of the large intestine. Fetuses from AL-fed cows had longer large intestines than those of ML-fed cows. However, DG had diverse effects on the mass and length of small and large intestines. Mass of small and large intestines were different at all studied DG. Heavier $(P$ 
Table 5. Effects of different day of gestation and feeding regimens on the mass of fetal organs in Holstein $\times$ Gyr cows (means \pm SEM)

\begin{tabular}{|c|c|c|c|c|c|c|c|c|c|}
\hline \multirow[b]{2}{*}{ Item } & \multicolumn{2}{|c|}{ Feeding regimen } & \multicolumn{4}{|c|}{ Day of gestation } & \multicolumn{3}{|c|}{$P$-value ${ }^{1}$} \\
\hline & Ad libitum & Maintenance & 139 & 199 & 241 & 268 & FR & DG & $\mathrm{FR} \times \mathrm{DG}$ \\
\hline Heart, $g$ & $117 \pm 1.4$ & $113 \pm 1.2$ & $14.9^{\mathrm{d}} \pm 1.92$ & $84.4^{\mathrm{c}} \pm 1.85$ & $143^{\mathrm{b}} \pm 1.85$ & $216^{\mathrm{a}} \pm 1.85$ & 0.62 & $<0.01$ & 0.42 \\
\hline $\mathrm{g} / \mathrm{kg}$ of fetal BW & $6.80+0.209$ & $7.16+0.192$ & $8.42^{\mathrm{a}}+0.302$ & $8.27^{\mathrm{a}}+0.272$ & $6.56^{\mathrm{b}}+0.272$ & $6.69 \mathrm{~b}+0.272$ & 0.85 & $<0.01$ & 0.23 \\
\hline Liver, $g$ & $383 \pm 2.2$ & $365 \pm 1.8$ & $57.1^{\mathrm{d}} \pm 2.3$ & $281^{\mathrm{c}} \pm 2.0$ & $447^{\mathrm{b}} \pm 2.0$ & $710^{\mathrm{a}} \pm 2.0$ & 0.52 & $<0.01$ & 0.85 \\
\hline $\mathrm{g} / \mathrm{kg}$ of fetal BW & $22.3 \pm 0.66$ & $23.1 \pm 0.61$ & $32.3^{\mathrm{a}} \pm 0.98$ & $27.5^{\mathrm{b}} \pm 0.89$ & $20.5^{\mathrm{c}} \pm 0.89$ & $22.0^{\mathrm{c}} \pm 0.89$ & 0.45 & $<0.01$ & 0.86 \\
\hline Kidneys, $g$ & $100 \pm 2.7$ & $90.6 \pm 2.61$ & $18.8^{\mathrm{d}} \pm 2.99$ & $88.7^{\mathrm{c}} \pm 2.87$ & $124^{\mathrm{b}} \pm 2.9$ & $151^{\mathrm{a}} \pm 2.9$ & 0.16 & $<0.01$ & 0.79 \\
\hline $\mathrm{g} / \mathrm{kg}$ of fetal BW & $5.81 \pm 0.272$ & $5.73 \pm 0.250$ & $10.6^{\mathrm{a}} \pm 0.41$ & $8.69^{\mathrm{b}} \pm 0.37$ & $5.69^{\mathrm{c}} \pm 0.37$ & $4.67^{\mathrm{c}} \pm 0.37$ & 0.94 & $<0.01$ & 0.96 \\
\hline Lungs, $g$ & $401 \pm 2.3$ & $381 \pm 1.8$ & $55.2^{\mathrm{d}} \pm 2.20$ & $260^{\mathrm{c}} \pm 2.12$ & $526^{\mathrm{b}} \pm 2.12$ & $723^{\mathrm{a}} \pm 2.12$ & 0.46 & $<0.01$ & 0.73 \\
\hline $\mathrm{g} / \mathrm{kg}$ of fetal BW & $23.3 \pm 0.70$ & $24.1 \pm 0.65$ & $31.2^{\mathrm{a}} \pm 1.04$ & $25.5^{\mathrm{b}} \pm 0.94$ & $24.1^{\mathrm{b}} \pm 0.94$ & $22.4^{\mathrm{c}} \pm 0.90$ & 0.48 & $<0.01$ & 0.12 \\
\hline Reticulum-rumen, $\mathrm{g}$ & $82.7 \pm 2.91$ & $79.6 \pm 2.70$ & $15.1^{\mathrm{d}} \pm 3.32$ & $74.1^{\mathrm{c}} \pm 3.19$ & $104^{\mathrm{b}} \pm 3.19$ & $131^{\mathrm{a}} \pm 3.19$ & 0.44 & $<0.01$ & 0.85 \\
\hline $\mathrm{g} / \mathrm{kg}$ of fetal BW & $4.81 \pm 0.175$ & $5.04 \pm 0.164$ & $8.53 \pm 0.261$ & $7.26 \pm 0.232$ & $4.77 \pm 0.232$ & $4.06 \pm 0.232$ & 0.89 & $<0.01$ & 0.02 \\
\hline Ad libitum & - & - & $9.34^{\mathrm{a}, \mathrm{A}} \pm 0.352$ & $7.15^{\mathrm{b}, \mathrm{A}} \pm 0.352$ & $4.54^{\mathrm{c}, \mathrm{A}} \pm 0.352$ & $4.04^{\mathrm{c}, \mathrm{A}} \pm 0.352$ & 0.0 & - & - \\
\hline Maintenance & - & - & $7.89^{\mathrm{a}, \mathrm{B}} \pm 0.356$ & $7.59^{\mathrm{a}, \mathrm{A}} \pm 0.322$ & $5.32^{\mathrm{b}, \mathrm{A}} \pm 0.322$ & $4.13^{\mathrm{c}, \mathrm{A}} \pm 0.322$ & - & - & - \\
\hline$P$-value & - & - & $<0.01$ & 0.19 & 0.36 & 0.85 & - & - & - \\
\hline Omasum, g & $33.4 \pm 0.73$ & $32.0 \pm 0.61$ & $7.93^{\mathrm{c}} \pm 0.745$ & $34.0^{\mathrm{b}} \pm 0.73$ & $44.4^{\mathrm{a}} \pm 0.73$ & $44.4^{\mathrm{a}} \pm 0.73$ & 0.57 & $<0.01$ & 0.19 \\
\hline $\mathrm{g} / \mathrm{kg}$ of fetal BW & $1.94 \pm 0.181$ & $2.03 \pm 0.174$ & $4.48^{\mathrm{a}} \pm 0.275$ & $3.33^{\mathrm{b}} \pm 0.252$ & $2.04^{\mathrm{c}} \pm 0.252$ & $1.37^{\mathrm{d}} \pm 0.252$ & 0.58 & $<0.01$ & 0.25 \\
\hline Abomasum, $\mathrm{g}$ & $70.1 \pm 0.69$ & $66.4 \pm 0.52$ & $7.35^{\mathrm{d}} \pm 0.844$ & $45.7^{\mathrm{c}} \pm 0.801$ & $87.5^{\mathrm{b}} \pm 0.801$ & $133^{\mathrm{a}} \pm 0.801$ & 0.46 & $<0.01$ & 0.14 \\
\hline $\mathrm{g} / \mathrm{kg}$ of fetal BW & $4.08+0.192$ & $4.20+0.181$ & $4.15+0.290$ & $4.48+0.266$ & $4.01+0.266$ & $4.11+0.266$ & 0.47 & 0.62 & 0.54 \\
\hline Spleen, $g$ & $42.8 \pm 0.88$ & $37.6 \pm 0.76$ & $4.19^{\mathrm{d}} \pm 0.98$ & $32.1^{\mathrm{c}} \pm 0.94$ & $50.7^{\mathrm{b}} \pm 0.94$ & $74.0^{\mathrm{a}} \pm 0.94$ & 0.19 & $<0.01$ & 0.80 \\
\hline $\mathrm{g} / \mathrm{kg}$ of fetal BW & $2.49 \pm 0.130$ & $2.38 \pm 0.125$ & $2.37 \pm 0.204$ & $2.55 \pm 0.185$ & $2.33 \pm 0.185$ & $2.29 \pm 0.185$ & 0.39 & 0.15 & 0.36 \\
\hline Bladder. $g$ & $16.6+0.11$ & $18.2+0.08$ & $2.75^{\mathrm{d}}+0.16$ & $10.4^{\mathrm{c}}+0.14$ & $22.3^{\mathrm{b}}+0.14$ & $34.3^{\mathrm{a}}+0.14$ & 0.29 & $<0.01$ & 0.15 \\
\hline $\mathrm{g} / \mathrm{kg}$ of fetal BW & $0.97 \pm 0.075$ & $1.15 \pm 0.064$ & $1.55^{\mathrm{a}} \pm 0.102$ & $1.02^{\mathrm{b}} \pm 0.092$ & $1.02^{\mathrm{b}} \pm 0.092$ & $1.06^{\mathrm{b}} \pm 0.092$ & $<0.01$ & $<0.01$ & 0.28 \\
\hline Gallbladder, $\mathrm{g}$ & $3.60 \pm 0.040$ & $3.03 \pm 0.031$ & $0.64^{\mathrm{d}} \pm 0.052$ & $2.72^{\mathrm{c}} \pm 0.049$ & $4.21^{\mathrm{b}} \pm 0.049$ & $5.70^{\mathrm{a}} \pm 0.049$ & 0.23 & $<0.01$ & 0.68 \\
\hline $\mathrm{g} / \mathrm{kg}$ of fetal BW & $0.21 \pm 0.020$ & $0.19 \pm 0.017$ & $0.36^{\mathrm{a}} \pm 0.034$ & $0.27^{\mathrm{ab}} \pm 0.030$ & $0.19^{\mathrm{b}} \pm 0.030$ & $0.18^{\mathrm{b}} \pm 0.030$ & 0.66 & $<0.01$ & 0.34 \\
\hline Diaphragm, g & $59.7 \pm 0.74$ & $49.1 \pm 0.69$ & $6.29^{\mathrm{d}} \pm 0.86$ & $36.3^{\mathrm{c}} \pm 0.83$ & $72.0^{\mathrm{b}} \pm 0.83$ & $103^{\mathrm{a}} \pm 0.8$ & 0.11 & $<0.01$ & 0.80 \\
\hline $\mathrm{g} / \mathrm{kg}$ of fetal BW & $3.47 \pm 0.126$ & $3.11 \pm 0.121$ & $3.55 \pm 0.194$ & $3.56 \pm 0.172$ & $3.30 \pm 0.172$ & $3.18 \pm 0.172$ & 0.01 & 0.19 & 0.21 \\
\hline
\end{tabular}

${ }^{\mathrm{a}-\mathrm{d}}$ Means within a row with different superscripts differ $(P \leq 0.10)$.

${ }^{\mathrm{A}, \mathrm{B}}$ Means within a column with different superscripts differ $(P \leq 0.10)$.

${ }^{1} \mathrm{FR}=$ feeding regimen main effects; $\mathrm{DG}=$ day of gestation main effects; $\mathrm{FR} \times \mathrm{DG}=$ interaction between feeding regimen and day of gestation 

and $241 \mathrm{~d}$ of gestation. The lowest $(P<0.01)$ masses of the small and large intestine were observed at $139 \mathrm{~d}$ of gestation.

The lengths of the small and large intestine were greater $(P<0.01)$ at 241 and $268 \mathrm{~d}$, with the shortest $(P<0.01)$ lengths being observed at $139 \mathrm{~d}$ of gestation. The length of the duodenum did not differ $(P=0.30)$ at 139, 199, and $241 \mathrm{~d}$. The lengths of the jejunum were highly variable $(P<0.01)$ among the studied DG. The greatest $(P<0.01)$ value was observed at $268 \mathrm{~d}$ and the least at $139 \mathrm{~d}$ of gestation. The lengths of the ileum were similar $(P=0.85)$ at 199,241 , and $268 \mathrm{~d}$ of gestation, with the smallest $(P<0.01)$ value at $139 \mathrm{~d}$ of gestation.

\section{DISCUSSION}

\section{Maternal Viscera and Organ Mass}

Blood plays many important roles in the body. Its major roles during gestation include transport of nutrients, oxygen, and wastes, as well as temperature regulation, immunity, communication, and defense (Ford, 1995). We therefore expected a greater amount of blood in AL-fed cows because those animals have more nutrients, oxygen, and waste to be transported. The amount of blood in the body is related to BW, and AL-fed cows had greater BW than ML-fed cows. However, we can infer that the amount of blood in the body is related mainly to BW because no difference was observed when considering the measurement expressed as grams per kilogram of EBW.

Sejrsen et al. (1982) evaluated the effect of nutrition on mammary development of pre- and postpubertal heifers that were fed 60:40 concentrate:roughage, either ad libitum or restricted to $60 \%$ of ad libitum. The ADG of feed-restricted heifers was 0.61 compared with 1.22 $\mathrm{kg} / \mathrm{d}$ for ad libitum heifers, and Sejrsen et al. (1982) observed that ad libitum feeding in the prepubertal group decreased mammary parenchymal tissue mass by $23 \%$ and decreased mammary DNA by $32 \%$ compared with the feed-restricted group. However, feeding level had no effect on postpubertal heifers, and the composition of mammary parenchyma was not affected by plane of nutrition.

Maintenance-fed cows demonstrated growth restriction in their mammary glands compared with AL-fed cows. However, this negative effect on the mammary gland caused by ML feeding might not have a negative influence on the subsequent lactation, because the $\mathrm{CP}$ concentration in the mammary gland increased with this FR. On the other hand, cows fed AL presented with a greater concentrations of fat in the mammary 
gland, which suggests a negative influence on the subsequent lactation because the excess fat pad negatively affects milk production (Capuco et al., 1997). Roche et al. (2007) evaluated the relationships among BCS, BW, and milk production variables in pasture-based dairy cows and concluded that the optimum calving BCS for milk production was approximately 3.5 on the 5 -point scale. Considering that in the present study, the BCS of AL-fed cows was approximately 4.5 on the 5 -point scale, we can infer that these cows were obese and that milk production may be decreased in the next lactation. Silva et al. (2002) studied the relationship between body growth and mammary development in dairy heifers and concluded that increased body fat was a better predictor of impaired mammary development than rapid BW gain; thus, if we consider that the same may occur in cows, we might infer that AL-fed cows may have impaired mammary glands because of the greater amount of fat deposition in the body, as observed by Rotta et al. (2015b).

Carlson et al. (2009) observed that when considering absolute mass, the heart was heavier in ewes fed at $100 \%$ of requirement than in those that were underfed. Ekpe et al. (2000) also described a greater heart mass in ewes fed an AL diet compared with those fed restricted diets. They also observed a positive relationship between heart mass and the density of $\beta 1$ adrenoceptors. According to Guyton (1976), a large heart may be associated with a greater force of contraction, and a greater number of $\beta 1$ adrenoceptors may favor development of a large force of contraction. Ekpe et al. (2000) reported that animals fed a restricted diet had fewer $\beta 1$ adrenoceptors in their heart membranes than those fed an AL diet.

A study by Carlson et al. (2009) supports the results that were observed in the present study regarding the liver, as they evaluated the effects of feed restriction during defined periods of gestation on maternal adaptations in ewes, and observed that animals fed approximately $0.9 \mathrm{~kg} / \mathrm{d}$ had heavier liver mass than those fed 0.7 and $0.5 \mathrm{~kg} / \mathrm{d}$. According to Reed et al. (2007), the liver is easily affected by nutrient restriction. Meyer et al. (2010a) studied the effect of nutrient restriction and day of gestation (125 and $245 \mathrm{~d}$ of gestation) in beef cows and observed an interaction between feeding regimen and day of gestation when evaluating liver mass. On d 125, the mass of the liver from nutrient-restricted cows was less than that of control cows with gain of $0.72 \mathrm{~kg} / \mathrm{d}$ according to the NRC (2000), but no difference was observed at $245 \mathrm{~d}$ of gestation (Meyer et al., 2010a). In contrast, in the present study, we did not observe interactions between FR and DG or any effects of DG on liver mass. Similar results were shown by Scheaffer et al. (2001), who evaluated the mass of liver at 40,120, 200, and $270 \mathrm{~d}$ of gestation. Those authors reported no effect of pregnancy or day of gestation on liver mass.

The increased kidney mass in AL- compared with ML-fed cows that was observed in the current study corroborates with results from Carlson et al. (2009), in which feeding nutrient-restricted diets to pregnant ewes reduced kidney mass. These studies evaluated different nutrient-restricted diets in pregnant sheep, and showed lower mass of kidney in ewes that were fed nutrient-restricted diets. The present results also agree with those of Ekpe et al. (2000), who studied different nutritional levels in ewes and observed that animals fed an AL diet had greater mass of kidney. Kasiske et al. (1988) demonstrated in obesity-prone animal models that excess body fat mass results in renal-specific consequences. Rotta et al. (2015b) demonstrated that fat deposition was greater in AL- than in ML-fed cows, and if we consider that the cows that were fed AL in this experiment received $190 \%$ of their energy for maintenance, we can infer that those cows were obese. In addition, Williams et al. (2007) observed an increased incidence of renal disease with obesity in rats and noted that prenatal malnutrition eliminated any renal histopathology associated with juvenile obesity.

According to Scarpace and Yu (1987), diet restriction in rats delayed the age-related loss of $\beta$-adrenergic receptors and adenylate cyclase activity in the lungs. They observed that dietary restriction prolonged the life span and delayed a variety of physiological processes that change with age. In dairy cattle, several studies have evaluated the effects of different physiological stages (prepartum, early lactation, and late lactation), different diets for heifers, and days relative to calving on organ mass (Andrew et al., 1994; Moallem et al., 2004; Reynolds et al., 2004). In beef cows, Wood et al. (2013) did not observe a difference in lung mass between cows that were fed at 85 and $140 \%$ of their nutritional requirements. According to Cesta (2006), the 3 main factors that affect spleen development are species, age, and genetic composition. However, we demonstrated in this study that FR also influences spleen mass.

Wood et al. (2013) demonstrated a greater rumen mass in cows that were fed $140 \%$ of their nutrient energy requirements compared with those fed $85 \%$. According to those authors, this may be due to greater rumen fill, which could influence rumen mass. However, when the rumen was measured relative to BW or hot carcass weight, no difference was observed in FR by those authors. We observed a relationship between reticulumrumen mass and DMI (Table 3 and Rotta et al., 2015b). From 199 d of gestation, DMI expressed as percentage of BW began decreasing in AL-fed cows, which coincides with the DG during which the reticulum-rumen 
mass also started decreasing (Rotta et al., 2015b). The lower rumen fill beginning at $199 \mathrm{~d}$ of gestation may be related to the decrease in reticulum-rumen mass expressed as kilograms or grams per kilogram of EBW.

Similar to our findings in the present study, Meyer et al. (2010a) also observed a greater omasum mass in beef cows fed a control diet that exceeded energy requirements with a gain of $0.72 \mathrm{~kg} / \mathrm{d}$ according to the NRC (2000) of cows that were fed a nutrient-restricted diet. Carlson et al. (2009) presented similar results for omasum mass; those authors studied the effect of a diet with $100 \%$ of NRC (2007) requirements and another with $60 \%$ of NRC (2007) requirements on pregnant ewes. Thus, the mass of both reticulum-rumen and omasum are affected by FR in pregnant dairy cows.

The greatest masses that were observed for small and large intestines expressed as grams per kilogram of EBW in ML-fed cows in this study may be because the gastrointestinal tract serves as the main site for nutrient absorption. Maintenance-fed cows showed changes in maternal visceral organs during pregnancy, which positively affected the fetuses, because no difference was observed in fetal weight between ML- and AL-fed cows (Table 4). Scheaffer et al. (2004a,b) and Reed et al. (2007) suggested that a dam may compensate for nutritional deficiency, thus sparing her offspring. In this way, gastrointestinal tissues in dairy cattle seem to be responsive to nutrient restriction. In addition, large intestine mass expressed as gram per kilogram of EBW may be responsive to DG, because it decreased at 241 and $268 \mathrm{~d}$ compared with that at $139 \mathrm{~d}$ of gestation.

\section{Fetal Viscera and Organ Mass}

Maternal FR during gestation had no effect on fetal weight or fetal eviscerated $\mathrm{BW}$ in the current study. These results are in agreement with previous studies conducted in dairy cows (Graugnard et al., 2012, 2013) and beef cows (Freetly et al., 2000, 2008; Meyer et al., 2010a). Some authors (Meyer et al., 2010b; Peel et al., 2012) observed similar birth weights in lambs born to ewes that were fed maintenance and high levels of nutrition. Differences between species seem to exist, even among ruminants. These differences may result from differences in timing of placental development and vascularization between species (Vonnahme et al., 2007). Osorio et al. (2013) observed that calf birth weight was affected by maternal diet, where cows that were fed a control diet had calved that were $5 \mathrm{~kg}$ heavier than calves from cows that were overfed. Moreover, Gao et al. (2012) found that the weights of the calves from cows that were fed a low-energy diet were reduced compared with those of the high-energy-diet group, demonstrat- ing that weight and measurements in neonatal calves were influenced by maternal energy density in the last $21 \mathrm{~d}$ of pregnancy. Although no effect of maternal FR was observed on fetal weight, FR affected fetal carcass weight expressed as gram per kilogram of fetal BW when the dams were fed ML. Similarly, fetal length, chest length, cranial circumference, and hip height were affected in fetuses from ML-fed cows. However, these differences were only about $5 \%$ and may not have a significant effect on dairy production, because those characteristics are more related to beef cattle performance (Fernandes et al., 2010; De Paula et al., 2013). Meyer et al. (2010a) also observed the same results regarding fetal visceral organ growth for fetuses from beef cows that were fed control and nutrient-restricted diets. According to those authors, accelerated or compensatory fetal organ growth rate may have occurred due to increased efficiency of nutrient usage by the dam, the fetus, or both during maternal restriction. Reduced mass of heart, liver, fat deposition (Rotta et al., 2015b), reticulum-rumen, omasum, abomasum, and small and large intestine for ML-fed cows that were observed in this study, combined with decreased heat production during nutrient restriction (Freetly et al., 2006), may have resulted in lower maintenance requirements for ML-fed cows.

Studies with ruminant and nonruminant animals have shown that fetuses from dams subjected to nutrient restriction during early to mid gestation demonstrated decreased growth of the gastrointestinal tract (Trahair et al., 1997; Wang et al., 2008). Even with adequate postnatal nutrition, the suboptimal growth caused permanent changes in gastrointestinal functions such as epithelial permeability (Trahair et al., 1997). However, these studies applied an intensive nutrient restriction that did not meet the energy requirements; in the present experiment, we applied a feed restriction but one that met the energy requirements for maintenance. Moreover, when studying ad libitum-fed or maintenance-fed beef cows, Duarte et al. (2013) observed that maternal feed restriction did not affect the development of most fetal gastrointestinal parts, except that the small intestine had an increased surface area as a response to maternal feed nutrition. The lack of effect of FR on the reticulum-rumen mass may be due to the nonfunctionality of these compartments at the fetal stage; theoretically, there is no need to expand the surface area of the stomach to increase nutrient absorption, as this occurs in the small intestine (Duarte et al., 2013).

As expected, fetal BW and all fetal visceral organs measured increased in weight during gestation; heavier masses were observed at $268 \mathrm{~d}$ than at 139, 199, and 241 $\mathrm{d}$ of gestation, with the exception of the omasum, which 
had similar masses at 241 and 268 d of gestation. Only the abomasum, spleen, and diaphragm showed growth proportional to that of the fetus, as no differences were observed in mass per unit of EBW in these tissues. Heart, liver, kidneys, lungs, omasum, bladder, and gallbladder had greater proportional masses expressed as grams per kilogram of fetal BW at $139 \mathrm{~d}$ of gestation, suggesting that these organs increased in weight more in early and mid gestation than in late gestation. Meyer et al. (2010a) observed that the abomasum and large intestine grew faster than the fetal body in later gestation in beef cows. However, none of the organs and tissues evaluated in the current study demonstrated this behavior. Similar results were observed by Duarte et al. (2013) in fetuses from beef cows that were fed ad libitum or maintenance diets. According to Weaver et al. (1991), the phase of rapid growth of the gastrointestinal tract occurs in the third trimester of gestation in species that have a long gestational period. However, in this study, we observed that approximately $70 \%$ of fetal growth occurred during the last 2 DG evaluated. For the organs and tissues, this value was around $60 \%$ of total growth in the last 2 DG. It has also been suggested that, even though the dam is undernourished, the placental system can compensate to provide the fetus an adequate amount of nutrients, mainly by increasing the number of caruncles (Clarke et al., 1998). This may have also contributed to the lack of effects of maternal feed restriction on fetal gastrointestinal tract mass. In the current study, we observed a greater placental mass and number of placentomes in cows that were fed the ML diet (Rotta et al., 2015a), which may have compensated for maternal feed restriction.

\section{CONCLUSIONS}

These data indicate that maternal feed restriction does not affect the development of most fetal organs and fetal development; however, some maternal organs are affected by the FR provided. The negative effect on mammary gland mass caused by ML feeding likely will not affect the subsequent lactation because the CP concentration in the mammary gland increased with this FR. However, we suggest that an AL diet in pregnant dry cows should be provided with caution because the amount of fat in the mammary gland increased at 268 $\mathrm{d}$ of gestation.

\section{REFERENCES}

Andrew, S. M., D. R. Waldo, and R. A. Erdman. 1994. Direct analysis of body composition of dairy cows at three physiological stages. J. Dairy Sci. 77:3022-3033. http://dx.doi.org/10.3168/jds.S00220302(94)77244-1.
AOAC International. 2000. Official Methods of Analysis. 17th ed. AOAC International, Arlington, VA.

AOAC International. 2006. Official methods of analysis. 18th ed. AOAC International, Gaithersburg, MD.

Brasil. 1997. Regulamento da Inspeção Industrial e Sanitária de Produtos de Origem Animal [Food of animal origin sanitary and industry inspection]. Ministério da Agricultura, Pecuária e Abastecimento, Brasilia, Brazil.

Capuco, A. V., R. M. Akers, and J. J. Smith. 1997. Mammary growth in Holstein cows during the dry period: Quantification of nucleic acids and histology. J. Dairy Sci. 80:477-487.

Carlson, D. B., J. J. Reed, P. P. Borowicz, J. B. Taylor, L. P. Reynolds, T. L. Neville, D. A. Redmer, K. A. Vonnahme, and J. S. Caton. 2009. Effects of dietary selenium supply and timing of nutrient restriction during gestation on maternal growth and body composition of pregnant adolescent ewes. J. Anim. Sci. 87:669-680. http://dx.doi.org/10.2527/jas.2007-0837.

Cesta, M. F. 2006. Normal structure, function, and histology of the spleen. Toxicol. Pathol. 34:455-465. http://dx.doi. org $/ 10.1080 / 01926230600867743$.

Clarke, L., L. Heasman, D. T. Juniper, and M. E. Symonds. 1998. Maternal nutrition in early-mid gestation and placental size in sheep. Br. J. Nutr. 79:359-364.

De Paula, N. F., L. O. Tedeschi, M. F. Paulino, H. J. Fernandes, and M. A. Fonseca. 2013. Predicting carcass and body fat composition using biometric measurements of grazing beef cattle. J. Anim. Sci. 91:3341-3351. http://dx.doi.org/10.2527/jas.2012-5233.

Drackley, J. K., R. L. Wallace, D. Graugnard, J. Vasquez, B. F. Richards, and J. J. Loor. 2014. Visceral adipose tissue mass in nonlactating dairy cows fed diets differing in energy density. J. Dairy Sci. 97:3420-3430. http://dx.doi.org/10.3168/jds.2014-8014.

Duarte, M. S., M. P. Giombelli, P. V. R. Paulino, N. V. L. Serao, T. S. Martins, P. I. S. Totaro, C. A. Neves, S. C. Valadares Filho M. V. Dodson, M. Zhu, and M. Du. 2013. Effects of maternal nutrition development of gastrointestinal tract of bovine fetus at different stages of gestation. Livest. Sci. 153:60-65. http://dx.doi. org/10.1016/j.livsci.2013.01.006.

Ekpe, E. D., J. A. Moibi, and R. J. Christopherson. 2000. Effects of temperature and plane of nutrition on beta-adrenergic receptors in heart, kidney, and liver of lambs. J. Anim. Sci. 78:1907-1916.

Fernandes, H. J., L. O. Tedeschi, M. F. Paulino, and L. M. Paiva. 2010. Determination of carcass and body fat compositions of grazing crossbred bulls using measurements. J. Anim. Sci. 88:14421453. http://dx.doi.org/10.2527/jas.2009-1919.

Ferrell, C. L. 1988. Energy metabolism. Pages 250-268 in The Ruminant Animal: Digestive Physiology and Nutrition. D. C. Church, ed. Prentice Hall, Englewood Cliffs, NJ.

Ford, S. P. 1995. Control of blood flow to the gravid uterus of domestic livestock species. J. Anim. Sci. 73:1852-1860.

Freetly, H. C., C. L. Ferrell, and T. G. Jenkins. 2000. Timing of realimentation of mature cows that were feed-restricted during pregnancy influences calf birth weights and growth rates. J. Anim. Sci. 78:2790-2796.

Freetly, H. C., J. A. Nienaber, and T. Brown-Brandl. 2006. Changes in heat production by mature cows after change in feeding level. J. Anim. Sci. 84:1429-1438.

Freetly, H. C., J. A. Nienaber, and T. Brown-Brandl. 2008. Partitioning of energy in pregnant beef cows during nutritionally induced weight fluctuation. J. Anim. Sci. 86:370-377. http://dx.doi. org/10.2527/jas.2007-0250.

Gao, F., Y. C. Liu, Z. H. Zhang, C. Z. Zhang, H. W. Su, and S. L. Li. 2012. Effect of prepartum maternal energy density on the growth performance, immunity, and antioxidation capability of neonatal calves. J. Dairy Sci. 95:4510-4518. http://dx.doi.org/10.3168/ jds.2011-5087.

Graugnard, D. E., M. Bionaz, E. Trevisi, K. M. Moyes, J. L. SalakJohnson, R. L. Wallace, J. K. Drackley, G. Bertoni, and J. J. Loor. 2012. Blood immunometabolic indices and polymorphonuclear neutrophil function in peripartum dairy cows are altered by level of dietary energy. J. Dairy Sci. 95:1749-1758. http://dx.doi. org/10.3168/jds.2011-4579. 
Graugnard, D. E., K. M. Moyes, E. Trevisi, M. J. Khan, D. Keisler, J. K. Drackley, G. Bertoni, and J. J. Loor. 2013. Liver lipid content and inflammometabolic indices in peripartal dairy cows are altered in response to prepartal energy intake and postpartal intramammary inflammatory challenge. J. Dairy Sci. 96:918-935. http:// dx.doi.org/10.3168/jds.2012-5676.

Guyton, A. C. 1976. Textbook of Medical Physiology. W. B. Saunders Company Philadelphia, PA.

He, Z. X., D. Q. Wu, Z. H. Sun, Z. L. Tan, J. Y. Qiao, T. Ran, S. X. Tang, C. S. Zhou, X. F. Han, M. Wang, J. H. Kang, and K. A. Beauchemin. 2013. Protein or energy restriction during late gestation alters fetal growth and visceral organ mass: An evidence of intrauterine programming in goats. Anim. Reprod. Sci. 137:177182. http://dx.doi.org/10.1016/j.anireprosci.2013.01.005.

IBGE. 2009. Censo Agropecuario. Accessed Dec. 8, 2014. http://www. ibge.gov.br/home/estatistica/economia/agropecuaria/censoagro/.

Kasiske, B. L., M. P. O'Donnell, M. P. Cleary, and W. F. Keane. 1988. Treatment of hyperlipidemia reduces glomerular injury in obese Zucker rats. Kidney Int. 33:667-672.

Meyer, A. M., J. J. Reed, T. L. Neville, J. B. Taylor, C. J. Hammer, L. P. Reynolds, D. A. Redmer, K. A. Vonnahme, and J. S. Caton. 2010b. Effects of plane of nutrition and selenium supply during gestation on ewe and neonatal offspring performance, body composition, and serum selenium. J. Anim. Sci. 88:1786-1800. http://dx.doi.org/10.2527/jas.2009-2435.

Meyer, A. M., J. J. Reed, K. A. Vonnahme, S. A. Soto-Navarro, L. P. Reynolds, S. P. Ford, B. W. Hess, and J. S. Caton. 2010a. Effects of stage of gestation and nutrient restriction during early to midgestation on maternal and fetal visceral organ mass and indices of jejunal growth and vascularity in beef cows. J. Anim. Sci. 88:2410-2424. http://dx.doi.org/10.2527/jas.2009-2220.

Moallem, U., G. E. Dahl, E. K. Duffey, A. V. Capuco, D. L. Wood, K. R. McLeod, and R. L. Baldwin. 2004. Bovine somatotropin and rumen-undegradable protein effects in prepubertal dairy heifers: Effects on body composition and organ and tissue weight. J. Dairy Sci. 87:3869-3880. http://dx.doi.org/10.3168/jds.S00220302(04)73526-2.

NRC. 2001. Nutrient Requirements of Dairy Cattle. 7th rev. ed. Natl. Acad. Press, Washington, DC.

NRC. 2007. Nutrient Requirements of Small Ruminants. 1st. ed. Natl. Acad. Press, Washington, DC.

Osorio, J. S., E. Trevisi, M. A. Ballou, G. Bertoni, J. K. Drackley, and J. J. Loor. 2013. Effect of the level of maternal energy intake prepartum on immunometabolic markers, polymorphonuclear leukocyte function, and neutrophil gene network expression in neonatal Holstein heifer calves. J. Dairy Sci. 96:3573-3587. http://dx.doi. org/10.3168/jds.2012-5759.

Peel, R. K., G. J. Eckerke, and R. V. Anthony. 2012. Effects of overfeeding naturally-mated adolescent ewes on maternal, fetal, and postnatal lamb growth. J. Anim. Sci. 90:3698-3708. http:// dx.doi.org/10.2527/jas.2012-5140.

Reed, J. J., M. A. Ward, K. A. Vonnahme, T. L. Neville, S. L. Julius, P. P. Borowicz, J. B. Taylor, D. A. Redmer, A. T. Grazul-Bilska, L. P. Reynolds, and J. S. Caton. 2007. Effects of selenium supply and dietary restriction on maternal and fetal body weight, visceral organ mass and cellularity estimates, and jejunal vascularity in pregnant ewe lambs. J. Anim. Sci. 85:2721-2733. http://dx.doi. org/10.2527/jas.2006-785.

Reynolds, C. K., B. Durst, B. Lupoli, D. J. Humphries, and D. E. Beever. 2004. Visceral tissue mass and rumen volume in dairy cows during the transition from late gestation to early lactation. J. Dairy Sci. 87:961-971. http://dx.doi.org/10.3168/jds.S00220302(04)73240-3.

Roche, J. R., J. M. Lee, K. A. Macdonald, and D. P. Berry. 2007. Relationships among body condition score, body weight, and milk production variables in pasture-based dairy cows. J. Dairy Sci. 90:3802-3815. http://dx.doi.org/10.3168/jds.2006-740.

Rotta, P. P., S. C. Valadares Filho, T. R. Santos, L. F. Costa e Silva, T. E. Engle, M. I. Marcondes, S. E. F. Guimaraes, C. S. Nascimento, B. C. Carvalho, F. A. S. Silva, and J. R. S. Oliveira. 2015a. Effects of days of gestation and feeding regimen in Holstein $\times$ Gyr cows: III. Placental adaptations and placentome gene expression. J. Dairy Sci. 98:3224-3235. 10.3168/jds.2014-8283.

Rotta, P. P., S. C. Valadares Filho, T. R. Santos, L. F. Costa e Silva, T. E. Engle, M. I. Marcondes, F. S. Machado, F. A. C. Villadiego, and L. H. R. Silva. 2015b. Effects of days of gestation and feeding regimen in Holstein $\times$ Gyr cows: I. Apparent total-tract digestibility, nitrogen balance, microbial protein supply, and fat deposition. J. Dairy Sci. 98:3197-3210. 10.3168/jds.2014-8280.

Scarpace, P. J., and B. P. Yu. 1987. Diet restriction retards the agerelated loss of beta-adrenergic receptors and adenylate cyclase activity in rat lung. J. Gerontol. 42:442-446.

Scheaffer, A. N., J. S. Caton, M. L. Bauer, and L. P. Reynolds. 2001. Influence of pregnancy on body weight, ruminal characteristics, and visceral organ mass in beef heifers. J. Anim. Sci. 79:24812490.

Scheaffer, A. N., J. S. Caton, D. A. Redmer, D. R. Arnold, and L. P. Reynolds. 2004a. Effect of dietary restriction, pregnancy, and fetal type on intestinal cellularity and vascularity in Columbia and Romanov ewes. J. Anim. Sci. 82:3024-3033.

Scheaffer, A. N., J. S. Caton, D. A. Redmer, and L. P. Reynolds. 2004b. The effect of dietary restriction, pregnancy, and fetal type in different ewe types on fetal weight, maternal body weight, and visceral organ mass in ewes. J. Anim. Sci. 82:1826-1838.

Sejrsen, K., J. T. Huber, and H. A. Tucker. 1983. Influence of amount fed on hormone concentrations and their relationship to mammary growth in heifers. J. Dairy Sci. 66:845-855.

Sejrsen, K., J. T. Huber, H. A. Tucker, and R. M. Akers. 1982. Influence of nutrition on mammary development in pre- and postpubertal heifers. J. Dairy Sci. 65:793-800. http://dx.doi.org/10.3168/ jds.1982-82268-6.

Silva, L. F. P., M. J. VandeHaar, B. K. Whitlock, R. P. Radcliff, and H. A. Tucker. 2002. Short communication: Relationship between body growth and mammary development in dairy heifers. J. Dairy Sci. 85:2600-2602. http://dx.doi.org/10.3168/jds.S00220302(02)74344-0

Smith, R. L., and R. L. Baldwin. 1973. Effects of breed, pregnancy, and lactation on weight of organs and tissues in dairy cattle. J. Dairy Sci. $\quad 57: 1055-1060 . \quad$ http://dx.doi.org/10.3168/jds.197385008-3.

Soto-Navarro, S. A., T. L. Lawler, J. B. Taylor, L. P. Reynolds, J. J. Reed, J. W. Finley, and J. S. Caton. 2004. Effect of high-selenium wheat on visceral organ growth selenium wheat on visceral organ mass, and intestinal cellularity and vascularity in finishing beef steers. J. Anim. Sci. 82:1788-1793.

Trahair, J. F., T. M. DeBarro, J. S. Robinson, and J. A. Owens. 1997. Restriction of nutrition in utero selectively inhibits gastrointestinal growth in fetal sheep. J. Nutr. 127:637-641.

Tucker, H. A. 1981. Physiological control of mammary growth, lactogenesis, and lactation. J. Dairy Sci. 64:1403-1421.

Vonnahme, K. A., M. J. Zhu, P. P. Borowicz, T. W. Geary, B. W. Hess, L. P. Reynolds, J. S. Caton, W. J. Means, and S. P. Ford. 2007. Effect of early gestational undernutrition on angiogenic factor expression and vascularity in the bovine placentome. J. Anim. Sci. 85:2464-2472. http://dx.doi.org/10.2527/jas.2006-805.

Wang, J., L. Chen, D. Li, Y. L. Yin, X. Wang, P. Li, L. J. Dangott, W. Hu, and G. Wu. 2008. Intrauterine growth restriction affects the proteomes of the small intestine, liver, and skeletal muscle in newborn pigs. J. Nutr. 138:60-66.

Weaver, L. T., S. Austin, and T. J. Cole. 1991. Small intestinal length: A factor essential for gut adaptation. Gut 32:1321-1323.

Williams, P. J., L. O. Kurlak, A. C. Perkins, H. Budge, T. Stephenson, D. Keisler, M. E. Symonds, and D. S. Gardner. 2007. Hypertension and impaired renal function accompany juvenile obesity: The effect of prenatal diet. Kidney Int. 72:279-289.

Wood, K. M., B. J. Awda, C. Fitzsimmons, S. P. Miller, B. W. Mc Bride, and K. C. Swanson. 2013. Effect of moderate dietary restriction on visceral organ weight, hepatic oxygen consumption, and metabolic proteins associated with energy balance in mature pregnant beef cows. J. Anim. Sci. 91:4245-4255. http://dx.doi. org/10.2527/jas.2013-6421. 